\title{
SINTESIS DAN KARAKTERISASI SELULOSA TERMETILASI SEBAGAI BIOKOMPOSIT HIDROGEL
}

\author{
NENG RITA NURJANNAH ${ }^{1}$, TETY SUDIARTI ${ }^{1}$, DAN LENA RAHMIDAR ${ }^{2 *}$ \\ ${ }^{1}$ Jurusan Kimia, Fakultas Sains dan Teknologi, UIN Sunana Gunung Djati Bandung, \\ Jl. A.H Nasution No. 105 Cibiru, Bandung \\ ${ }^{2}$ Material Science Research Group, Universitas ARS, \\ Jl. Sekolah Internasional Antapani, Bandung \\ *alamat email korespondensi: lena@ars.ac.id
}

\section{Informasi Artikel}

Riwayat Naskah :

Diterima pada 23

November 2019

Diterima setelah

direvisi pada 22 Juni

2020

Diterbitkan pada 30

Juni 2020

Kata Kunci: batang, pisang, Acetobacter; xylinum, selulosa, mikrobial, metil, selulosa, FTIR.

Abstrak/Abstract

Penggunaan biomaterial di bidang klinis semakin banyak dilakukan, karena biomaterial lebih aman digunakan (tidak toksik) serta ketersediaannya di alam sangat banyak. Salah satu pemanfaatan biomaterial ini adalah yang berasal serat batang pisang. Serat batang pisang ini merupakan prekursor untuk disintesis menjadi Metil Selulosa (MS) yang bisa digunakan sebagai bahan hidrogel untuk proses penyembuhan luka dan iritasi kulit. Penelitian ini dimulai dari sintesis selulosa mikrobial dari batang pisang dengan menggunakan starter Acetobacter xylinum yang diinkubasi selama 9 hari. Nata yang diperoleh dimurnikan dan dihasilkan selulosa mikrobial. Selulosa mikrobial yang dihasilkan kemudian disintesis menjadi metil selulosa. Metil selulosa disintesis secara swelling, kemudian ditambahkan pelarut dan metilen klorida untuk proses metilasi. Selulosa dan metil selulosa dianalisis FTIR dan dilakukan pengujian pada metil selulosa meliputi warna, titik leleh serta kelarutan, sehingga dapat diperkirakan nilai DSnya. Hasil karakterisasi FTIR pada selulosa mikrobial terdapat gugus - $\mathrm{OH}$ pada bilangan gelombang 3388,93 $\mathrm{cm}^{-1}$ dan gugus -CH pada bilangan gelombang $2931,80 \mathrm{~cm}^{-1}$. Karakterisasi metil selulosa dengan FTIR dapat diketahui dengan munculnya puncak daerah serapan gugus - $\mathrm{CH}$ yang semakin tajam, yaitu pada MS-air dan MS-aseton terdapat gugus - $\mathrm{CH}$ masingmasing pada panjang gelombang $2918,30 \mathrm{~cm}^{-1}$ dan $2900,94 \mathrm{~cm}^{-1}$. Metil selulosa hasil sintesis dari batang pisang tidak dapat larut dalam pelarut air dingin $\left(0-15^{\circ} \mathrm{C}\right), \mathrm{NaOH} 4 \%$ dan asam asetat glasial. Nilai Derajat Substitusi (DS) MS-aseton 0,912 dan MS-air 0,834, sehingga pelarut aseton lebih baik untuk mengoptimalkan nilai DS pada metil selulosa.
\end{abstract}

Keywords: banana, stem, Acetobacter, xylinum, cellulose, microbial, methyl, cellulose, FTIR.

\begin{abstract}
The use of biomaterial in clinical research has increased due to safe characteristics (non-toxic) and its abundant availability. One of its uses is from banana stem fiber. This banana stem fiber is a precursor for synthesizing methyl cellulose (MC) that can be used as a hydrogel for wound healing and skin irritation. This research was started from incubating microbial cellulose synthesis of the banana stem used Acetobacter xylinum starter for 9 days. The obtained Nata was purified and produced microbial cellulose. Then it was synthesized to be methyl cellulose. The methyl cellulose was synthesized by swelling, then added solvent and methylene chloride for the methylation process. Cellulose and methyl cellulose were analyzed by FTIR and tested on methyl cellulose including color, melting point and solubility so it can be estimated DS value. FTIR characterization result on microbial cellulose was obtained-OH group at wave number $3388.93 \mathrm{~cm}^{-1}$ and $-\mathrm{CH}$ group at wave number $2931.80 \mathrm{~cm}^{-1}$. Characterization of methyl cellulose by FTIR can be known by appearance the peak of the group absorption area of -CH was getting sharper. i.e. MC-water and MC-acetone have a-CH group at wavelengths $2918.30 \mathrm{~cm}^{-1}$ and $2900.94 \mathrm{~cm}^{-1}$, respectively. Methyl cellulose produced from the synthesis result of banana stem is insoluble in cold water solvents $\left(0-15^{\circ} \mathrm{C}\right), 4 \% \mathrm{NaOH}$ and glacial acetic acid. The substitution degrees $(D S)$ values of MS-acetone 0.912 and MS-water 0.834, so acetone solvent is better for optimizing DS values in methyl cellulose.
\end{abstract}

\section{PENDAHULUAN}

Pisang (Musa balbisiana Colla) merupakan tumbuhan yang dapat hidup di daerah tropis dan subtropis. Tumbuhan berbatang basah, yang tingginya bisa sampai $6 \mathrm{~m}$, daunnya lebar berbentuk sudip dan tepinya tak bertulang. Bunganya deret berganda, dilindungi oleh seludang bunga yang berwarna lembayung. Dalam buah pisang kepok terkandung zat seperti protein, karbohidrat, kalsium, fosfor, besi, vitamin A, B, C, dan zat metabolit sekunder lainnya [1].

Pisang (Musa balbisiana Colla) merupakan buah-buahan yang bernilai ekonomis tinggi dan banyak digemari oleh masyarakat baik sebagai makanan langsung maupun sebagai bahan olahan. 
Selama ini pisang hanya dimanfaatkan pada buah dan daunnya, sedangkan batang pisang kurang banyak dimanfaatkan. Batang pisang merupakan limbah dari tanaman pisang yang telah ditebang untuk diambil buahnya dan merupakan limbah pertanian berpotensial yang belum banyak pemanfaatannya. Beberapa penelitian telah mencoba untuk memanfaatkannya antara lain untuk papan partikel dan papan serat [2]. Bagi sebagian masyarakat, batang pisang hanya salah satu limbah yang tidak berguna. Meskipun batang pisang termasuk sampah organik, apabila tidak dimanfaatkan secara optimal penumpukan sampah ini dapat berpotensi menjadi limbah yang dapat mencemari lingkungan.

Batang pisang dapat dimanfaatkan untuk diambil patinya, pati ini menyerupai pati tepung sagu dan tepung tapioka. Potensi kandungan pati batang pisang yang besar dapat dimanfaatkan sebagai bahan dasar sintesis selulosa dan turunannya, selain itu juga umur panen dan usaha tani lebih fleksibel [3]. Serat batang pisang merupakan serat yang berkualitas baik. Batang pisang sebagai limbah dapat dimanfaatkan menjadi sumber serat yang mempunyai nilai ekonomis. Rahman (2006) menyatakan bahwa perbandingan bobot segar antara batang, daun, dan buah pisang berturut-turut $63 \%$, $14 \%$, dan $23 \%$. Batang pisang memiliki bobot jenis $0,29 \mathrm{~g} / \mathrm{cm}^{3}$ dengan ukuran panjang serat $4,20-5,46 \mathrm{~mm}$ dan kandungan lignin $33,51 \%$ [4].

Serat batang pisang ini, tersusun atas selulosa, hemiselulosa, dan kadang-kadang mengandung pula lignin. Selulosa merupakan komponen struktural utama dinding sel tumbuhan hijau. Selain ditemukan alami pada tunbuhan, selulosa dapat juga diproduksi oleh bakteri. Jenis selulosa ini disebut dengan bioselulosa atau selulosa mikrobial. Selulosa tumbuhan dan selulosa mikrobial memiliki struktur kimia yang sama, namun sifat fisik dan kimianya berbeda. Salah satu keunggulan selulosa mikrobial adalah kemurniannya yang tinggi jika dibandingkan dengan selulosa tumbuhan yang menghasilkan lignin dan produk hemiselulosa lainnya. Beberapa senyawa turunan selulosa diperoleh dengan mengganti beberapa gugus hidroksil dalam rantai selulosa dengan bermacam-macam gugus organik. Ini akan mengubah struktur kristal selulosa dan menjadikannya mudah terdispersi dalam air. Perubahan sifat hidrofilik ada hubungannya dengan derajat substitusi. Turunan selulosa telah digunakan secara luas dalam sediaan farmasi dan bahan tambahan makanan seperti etil selulosa, metil selulosa, karboksimetil selulosa, dan dalam bentuk lainnya yang digunakan dalam sediaan oral, topikal, dan injeksi. Penggunaan bentuk-bentuk selulosa dalam sediaan disebabkan sifatnya yang inert dan biokompatibilitas yang sangat baik pada manusia [5].

Salah satu fungsi dari metil selulosa yaitu sebagai zat aditif makanan yang merupakan pengemulsi. Pengemulsi adalah zat yang dapat mempertahankan dispersi lemak dalam air dan sebaliknya. Dalam konteks aditif makanan, pengemulsi adalah bahan tambahan pangan untuk membantu terbentuknya campuran yang homogen dari dua atau lebih fasa yang tidak tercampur seperti minyak dan air [6]. Pengemulsi makanan memiliki nilai Derajat Substitusi (DS) sekitar 1,3 2,6, yang akan larut pada air dingin.

Penelitian ini bertujuan untuk memanfaatkan limbah batang pisang sebagai bahan baku untuk sintesis metil selulosa. Dalam penelitian ini selulosa dibuat dengan starter Acetobacter xylinum dan sintesis metil selulosa dengan penambahan metilen klorida. Metil selulosa dikarakterisasi dengan menggunakan FTIR.

\section{EKSPERIMEN}

\section{Bahan}

Bahan-bahan yang akan digunakan dalam penelitian ini adalah batang pisang, ammonium sulfat $\left(\left(\mathrm{NH}_{4}\right)_{2} \mathrm{SO}_{4}\right)$ teknis, gula pasir, starter Acetobacter xylinum, natrium hidroksida $(\mathrm{NaOH})$ pa, asam asetat $\left(\mathrm{CH}_{3} \mathrm{COOH}\right) \mathrm{pa}$, metilen klorida $99,8 \%$, aseton $99,9 \%$, alkohol $70 \%$, dan akuades.

\section{Prosedur}

Pada penelitian ini dilakukan dalam 5 tahapan di antaranya yaitu sintesis selulosa mikrobial batang pisang, pemurnian selulosa mikrobial, sintesis metil selulosa, karakterisasi menggunakan Spectroscopy Fourier Transform Infrared (FTIR), serta uji sifat fisika kimia metil selulosa, meliputi pengujian warna, titik leleh dan kelarutan dalam air, asam asetat glasial dan $\mathrm{NaOH}$.

\section{Sintesis Selulosa Mikrobial Batang Pisang}

Batang pisang dicuci sampai bersih, dipotong kecil-kecil kemudian diblender sampai halus, disaring untuk diambil cairan konsentratnya. Selanjutnya konsentrat tersebut dipanaskan pada suhu $100^{\circ} \mathrm{C}$ hingga mendidih, kemudian ditambahkan gula pasir $60 \mathrm{~g}$ dan $\left(\mathrm{NH}_{4}\right)_{2} \mathrm{SO}_{4} 15 \mathrm{~g}$, diaduk, lalu didinginkan dan diatur $\mathrm{pH}$-nya sampai 4. Starter Acetobacter xylinum dimasukkan ke dalam campuran tersebut dengan jumlah starter Acetobacter xylinum $200 \mathrm{~mL}$ dalam $50 \mathrm{~mL}$ konsentrat pada botol zat plastik. Pada penelitian 
ini digunakan waktu inkubasi selama 9 hari, sehingga dihasilkan selulosa mikrobial berupa gel berwarna keputih-putihan dengan ketebalan $3 \mathrm{~mm}$ hingga $8 \mathrm{~mm}$ dan permukaannya licin.

\section{Pemurnian Selulosa Mikrobial}

Proses pemurnian selulosa mikrobial dimulai dengan merendam selulosa mikrobial yang dihasilkan dalam larutan $\mathrm{NaOH}$ sebanyak $50 \mathrm{~mL}$ selama 24 jam, ditutup dengan alumunium foil. Selanjutnya selulosa mikrobial direndam dalam $\mathrm{CH}_{3} \mathrm{COOH}$ sebanyak $50 \mathrm{~mL}$ selama 24 jam, ditutup dengan alumunium foil. Setelah direndam dengan asam asetat, kemudian selulosa mikrobial direndam dengan air berulang kali sampai bau asam hilang dan selanjutnya dikeringkan dengan menggunakan oven pada suhu $60^{\circ} \mathrm{C}$ selama 6 jam.

\section{Sintesis Metil Selulosa}

Selulosa mikrobial hasil pemurnian masingmasing dimasukkan ke dalam 2 buah labu Erlenmeyer sebanyak $1 \mathrm{~g}$. Selanjutnya selulosa mikrobial direndam dalam $\mathrm{NaOH} 50 \%$ pada suhu ruang selama 24 jam dan diaduk. Setelah 24 jam cairan bekas rendaman dibuang. Selanjutnya ditambahkan $9 \mathrm{~mL}$ aseton pada salah satu labu Erlenmeyer dan $20 \mathrm{~mL}$ aquades pada labu Erlenmeyer lainnya. Campuran dimasukkan ke dalam labu alas bulat dan ditambahkan tetes demi tetes $10 \mathrm{~mL}$ metilen klorida ke dalam masingmasing campuran dan dilakukan refluks pada suhu $50^{\circ} \mathrm{C}$ selama 12 jam. Selanjutnya campuran dinetralkan dengan penambahan asam asetat $10 \%$, kemudian disaring dan dicuci dengan air hangat. Substrat yang diperoleh dikeringkan dalam oven pada suhu $50^{\circ} \mathrm{C}$ selama 6 jam [7].

Karakterisasi Selulosa Mikrobial dan Metil Selulosa dengan Fourier Transform InfraRed (FTIR)

Sampel selulosa mikrobial dan metil selulosa digerus bersamaan dengan $\mathrm{KBr}$, setelah homogen dituangkan ke dalam $\mathrm{KBr}$ Die, kemudian diberi tekanan $10 \times 1.000 \mathrm{~kg}$ atau setara dengan 10 ton untuk membuat pelet. Sampel tersebut dianalisis menggunakan instrumen FTIR.

\section{Uji Sifat Fisika dan Kimia Metil Selulosa}

Metil selulosa hasil sintesis yang diperoleh, dilakukan pengujian warna, kelarutan dan titik leleh. Pengujian warna dilihat secara kasat mata. Pengujian kelarutan yaitu dengan dilarutkannya sedikit metil selulosa ke dalam air $5^{\circ} \mathrm{C}, \mathrm{NaOH} 4 \%$ dan asam asetat glasial. Pengujian titik leleh dilakukan dengan memakai pipa kapiler yang digantung di atas media air panas alas bulat dan ditambahkan tetes demi tetes $10 \mathrm{~mL}$ metilen klorida ke dalam masing-masing campuran, dan dilakukan refluks pada suhu $50^{\circ} \mathrm{C}$ selama 12 jam. Selanjutnya campuran dinetralkan dengan penambahan asam asetat $10 \%$, kemudian disaring dan dicuci dengan air hangat. Substrat yang diperoleh dikeringkan dalam oven pada suhu $50^{\circ} \mathrm{C}$ selama 6 jam.

\section{Karakterisasi Selulosa Mikrobial dan Metil Selulosa dengan Fourier Transform InfraRed}

Sampel selulosa mikrobial dan metil selulosa digerus bersamaan dengan $\mathrm{KBr}$, setelah homogen dituangkan ke dalam $\mathrm{KBr}$ Die, kemudian diberi tekanan $10 \times 1.000 \mathrm{~kg}$ atau setara dengan 10 ton untuk membuat pelet. Sampel tersebut dianalisa menggunakan instrumen FTIR.

\section{Uji Sifat Fisika dan Kimia Metil Selulosa}

Metil selulosa yang diperoleh dilakukan pengujian warna, kelarutan dan titik leleh. Pengujian warna dilihat secara kasat mata. Pengujian kelarutan yaitu dengan dilarutkannya sedikit metil selulosa ke dalam air $5^{\circ} \mathrm{C}, \mathrm{NaOH} 4 \%$ dan asam asetat glasial. Pengujian titik leleh dilakukan dengan memakai pipa kapiler yang digantung di atas media air panas.

\section{HASIL DAN PEMBAHASAN}

\section{Sintesis Selulosa Mikrobial Batang Pisang}

Sintesis selulosa mikrobial dibuat dari konsentrat batang pisang, gula pasir, amonium sulfat dan bakteri Acetobacter xylinum. Batang pisang yang telah dikupas bagian luarnya, kemudian dicuci untuk dibersihkan dari kotorankotoran yang menempel. Setelah itu, batang pisang yang sudah bersih dipotong kecil-kecil untuk memudahkan pada proses blender yang selanjutnya disaring untuk memperoleh cairan konsentrat batang pisang. Konsentrat batang pisang digunakan sebagai media pertumbuhan bakteri Acetobacter xylinum, karena nutrisi yang terkandung di dalamnya dapat dimanfaatkan oleh bakteri. Konsentrat batang pisang dilakukan pendidihan yang bertujuan untuk membunuh jamur dan bakteri yang tidak diinginkan yang dapat mengganggu proses fermentasi pembuatan selulosa mikrobial batang pisang. Selain itu konsentrat batang pisang yang panas juga akan mempercepat proses pelarutan bahan yaitu gula pasir. Bakteri Acetobacter xylinum selain membutuhkan media pertumbuhan juga memerlukan nutrisi lain sebagai sumber karbon dan nitrogen, sehingga dalam media 
tersebut ditambahkan gula pasir dan amonium sulfat. Gula pasir ditambahkan ke dalam media sebagai sumber makanan tambahan dan sumber karbon untuk pertumbuhan bakteri. Amonium sulfat ditambahkan sebagai sumber nitrogen yang berguna untuk pembentukan protein yang penting pada pembentukan enzim dan pertumbuhan sel. Campuran didiamkan sampai temperatur kamar dan $\mathrm{pH} 4$ untuk mengotimalkan pertumbuhan bakteri. Pendinginan sampai temperatur kamar dilakukan karena bakteri Acetobacter xylinum memiliki temperatur optimum sekitar $25-27^{\circ} \mathrm{C}$. Apabila bakteri dimasukkan ketika campuran panas atau pada suhu yang terlalu tinggi, maka bakteri Acetobacter xylinum akan mati. Selain itu bakteri Acetobacter xylinum dapat tumbuh pada tingkat keasaman tertentu. Campuran yang telah siap ditambahkan starter Acetobacter xylinum. Bakteri ini digunakan karena mampu menghasilkan selulosa yang baik yang ikatan glikosidik selulosanya lebih kuat dibandingkan dengan bakteri lainnya [8].

Proses inkubasi dilakukan di dalam wadah plastik yang sudah disterilisasi dan ditutup dengan menggunakan koran supaya terdapat rongga untuk masuknya oksigen. Inkubasi dilakukan selama 9 hari, karena selulosa mikrobial terbentuk selama 9 hari. Faktor-faktor yang mempengaruhi proses pembentukan selulosa mikrobial sehingga mempengaruhi ketebalan nata yang diperoleh, sangat berhubungan dengan faktor-faktor yang mempengaruhi pertumbuhan bakteri Acetobacter xylinum yaitu, sumber nutrisi (karbon dan nitrogen), temperatur ruangan, tingkat keasaman media ( $\mathrm{pH})$, dan oksigen. Selain itu, sterilisasi alat dan sterilisasi ruangan yang digunakan juga sangat mempengaruhi proses pertumbuhan bakteri maupun pembuatan selulosa mikrobial. Bakteri Acetobacter xylinum mengalami fase pertumbuhan yaitu fase adaptasi, fase pertumbuhan awal, fase eksponensial, fase pertumbuhan lambat, fase pertumbuhan tetap dan fase kematian. Fase adaptasi berlangsung pada 0-24 jam dimana starter bakteri akan beradaptasi dengan media baru dan belum terbentuk nata. Fase pertumbuhan awal terjadinya pembelahan sel dengan kecepatan yang rendah selama beberapa jam. Fase eksponensial yaitu bakteri akan mengeluarkan enzim ekstraseluler polimerase sebanyak-banyaknya untuk menyusun polimer glukosa menjadi selulosa pada hari ke-1 sampai ke-5. Fase tetap yaitu pada hari ke-9, terjadinya keseimbangan antara sel yang mati dan sel yang tumbuh, dimana produksi nata lebih banyak [9].

Pada Gambar 1 terlihat selulosa mikrobial yang disintesis dari batang pisang terbentuk berupa nata berwarna putih dengan ketebalan sekitar 0,5 $\mathrm{cm}$. Nata ini terbentuk dari monomer-monomer selulosa dari hasil sekresi Acetobacter xylinum yang terus berikatan satu dengan yang lainnya sehingga membentuk lapisan yang terus menebal seiring dengan berlangsungnya metabolisme Acetobacter xylinum. Semakin banyak hasil sekresi Acetobacter xylinum, maka semakin tebal selulosa mikrobial yang dihasilkan.

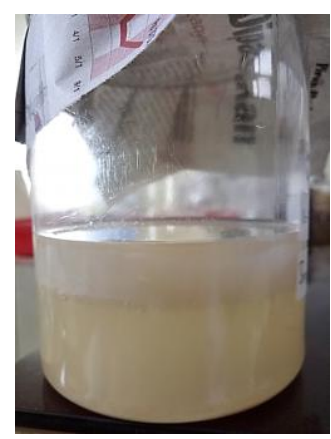

Gambar 1. Selulosa mikrobial batang pisang

Pada proses metabolismenya, selaput selulosa terbentuk oleh aktivitas Acetobacter xylinum terhadap nutrien yang terdapat pada konsentrat batang pisang dan larutan gula. Nutrien yang berperan dalam pembentukkan selulosa mikrobial adalah nutrien yang mengandung glukosa sehingga akan membentuk prekursor (penciri nata). Karbohidrat pada konsentrat batang pisang dipecah menjadi glukosa, kemudian berikatan dengan asam lemak (Guanosin trifosfat) membentuk prekursor penciri selulosa sintetase yang selanjutnya dikeluarkan ke lingkungan dalam bentuk ekskresi dengan enzim sintetase selulosa mempolimerisasi glukosa membentuk jalinan selulosa pada permukaan medium. Selulosa terbentuk dari pelepasan lendir Acetobacter xylinum yang merupakan hasil sekresi proses metabolisme gula yang ditambahkan pada konsentrat [10].

Pembentukan selulosa mikrobial dari konsentrat batang pisang terdiri dari tiga tahap reaksi. Tahapan pertama yaitu terjadinya hidrolisis kandungan utama gula pasir, sukrosa menghasilkan fruktosa dan glukosa. Berikut reaksi yang terjadi:

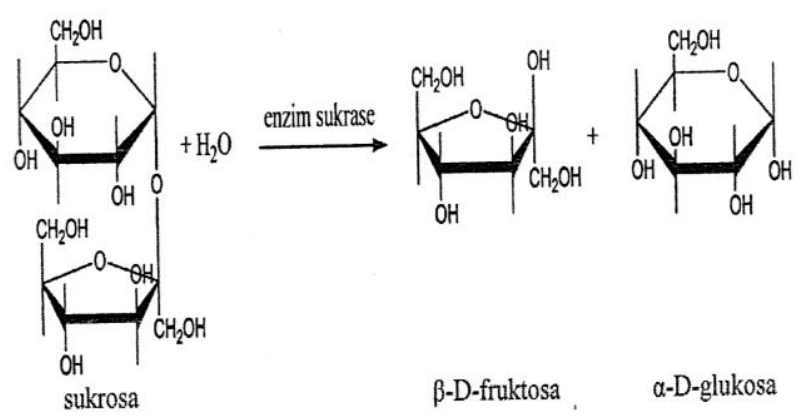

Gambar 2. Reaksi hidrolisis sukrosa 
Pada Gambar 2 sukrosa dihidrolisis dengan enzim sukrase yang berperan sebagai katalis dalam penguraian sukrosa menjadi glukosa dan fruktosa. Tahapan kedua yaitu reaksi pengubahan intermolekul a-D-glukosa dari konsentrat batang pisang dengan menggunakan enzim isomerase yang terdapat dalam Acetobacter xylinum menjadi $\beta$-D-glukosa. Perubahan ini disebabkan glukosa yang berperan dalam pembentukanselulosa mikrobial adalah dalam bentuk $\beta$. Tahapan ketiga merupakan reaksi intermolekul glukosa melalui ikatan 1,4 $\beta$-glikosida. Terakhir, tahap keempat merupakan reaksi polimerisasi yang merupakan pembentukan selulosa mikrobial, dengan unit ulangnya yaitu selobiosa [11]. Jenis polimerisasi yang terjadi merupakan polimerisasi kondensasi dengan mengeliminasi air. Reaksi yang terjadi sebagai berikut:

\section{Pemurnian Selulosa Mikrobial}

Proses pemurnian selulosa mikrobial dari batang pisang dilakukan dengan perendaman. Perendaman pertama selulosa mikrobial yaitu dalam larutan $\mathrm{NaOH}$, selama 24 jam. Larutan $\mathrm{NaOH}$ menjadi berwarna kuning kecoklatan dan selulosa mikrobial menjadi warna putih kekuningan. Warna kuning ini berupa bercak yang diperkirakan merupakan jamur yang tumbuh akibat proses fermentasi terlalu lama. Hal ini terjadi akibat nutrisi yang terdapat didalam konsentrat batang pisang mulai habis. Perendaman ini bertujuan untuk menghilangkan sisa bakteri dan komponenkomponen non-selulosa dalam selulosa mikrobial. Komponen-komponen non-selulosa ini berupa lignin dan hemiselulosa. Keberadaan lignin dalam selulosa mikrobial akan menghalangi ikatan hidrogen yang terjadi antar molekul selulosa.

Perendaman dengan $\mathrm{NaOH}$ akan menyebabkan molekul lignin terdegradasi pada bagian kristalin dan amorf serta sebagian hemiselulosa. Hemiselulosa memiliki struktur amorf sehingga penggunaan $\mathrm{NaOH}$ dapat menghilangkan lignin sekaligus mengekstraksi hemiselulosa. Ion $\mathrm{OH}^{-}$dari $\mathrm{NaOH}$ memutuskan ikatan-ikatan dari struktur dasar lignin yaitu ikatan aril-eter, karbon-karbon, aril-aril dan alkil-alkil. Sedangkan ion $\mathrm{Na}^{+}$akan berikatan dengan lignin membentuk natrium fenolat yang dapat dilihat pada Gambar 3. Garam fenolat ini bersifat mudah larut. Adanya lignin pada senyawa tersebut ditandai dengan adanya larutan berwarna hitam pekat. Warna hitam yang ditimbukan saat perendaman dengan $\mathrm{NaOH}$ merupakan indikasi dari terlarutnya senyawa-senyawa yang memiliki gugus kromofor yaitu gugus yang memiliki ikatan rangkap terkonjugasi yang menyebabkan suatu senyawa memiliki warna dan dapat menyerap cahaya dengan panjang gelombang antara $200-400 \mathrm{~nm}$ (UV) [12].

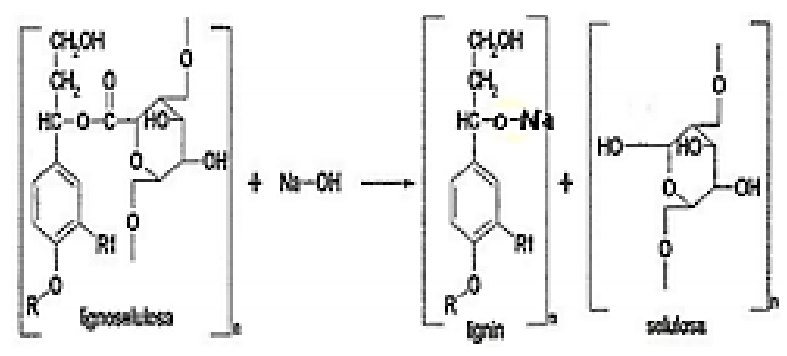

Gambar 3. Reaksi pemutusan ikatan lignoselu-losa menggunakan $\mathrm{NaOH}$ [13].

Perendaman dengan $\mathrm{NaOH}$ pada Gambar 4 membuat tingkat kemurnian selulosa mikrobial dari batang pisang semakin tinggi, karena terdegradasinya komponen non-selulosa seperti lignin dan hemiselulosa. Ikatan hidrogen yang terbentuk antar rantai molekul selulosa semakin kuat sehingga struktur selulosa mikrobial semakin rapat. Selain itu, selulosa mikrobial menjadi berwarna putih bersih yang menunjukkan tidak adanya jamur. Untuk mengetahui bahwa selulosa mikrobial dari batang pisang tidak mengandung lignin, maka filtrat berwarna jernih.

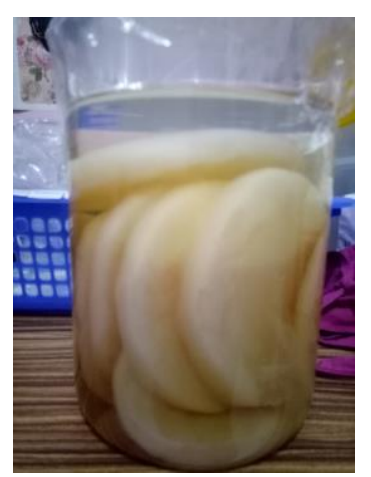

Gambar 4. Perendaman selulosa mikrobial dengan $\mathrm{NaOH}$

Langkah selanjutnya yaitu perendaman dengan larutan asam asetat, selama 24 jam yang dapat dilihat pada Gambar 5. Tujuan dari perendaman dengan asam asetat yaitu untuk menetralkan $\mathrm{NaOH}$ yang masih menempel pada selulosa mikrobial. Setelah direndam dengan asam asetat, kemudian selulosa mikrobial dicuci berulang kali dengan air. Pencucian ini bertujuan untuk menghilangkan bau asam pada selulosa mikrobial. Selanjutnya selulosa mikrobial dikeringkan dalam oven pada suhu $60^{\circ} \mathrm{C}$, suhu yang digunakan tidak terlalu tinggi agar tidak merusak struktur selulosa mikrobial sehingga dapat digunakan kembali untuk sintesis metil selulosa. 


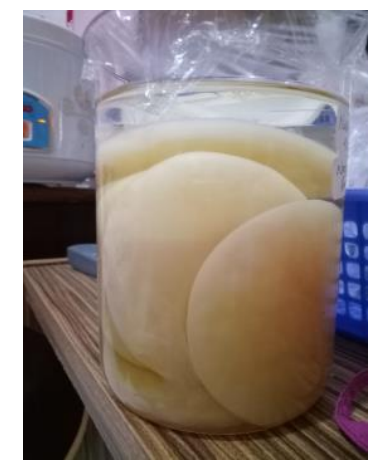

Gambar 5. Perendaman selulosa mikrobial denga asam asetat

Selulosa mikrobial dari batang pisang setelah dilakukan pengeringan di dalam oven diatas tempat rata dengan luas tertentu dihasilkan selulosa mikrobial berwarna coklat. Gugus $\mathrm{OH}$ dalam air lebih reaktif daripada gugus $\mathrm{OH}$ pada komponen lignoselulosa, sehingga hidrolisis berlangsung lebih cepat daripada substitusi. Suhu untuk reaksi sempurna pada selulosa mikrobial sudah cukup rendah yaitu dibawah $150^{\circ} \mathrm{C}$ sehingga tidak terjadi degradasi serat. Warna coklat diperkirakan akibat bawaan dari penyakit busuk batang pisang yang disebabkan oleh bakteri dan jamur sehingga terjadi gejala khas yaitu pencoklatan seperti Gambar 6 .

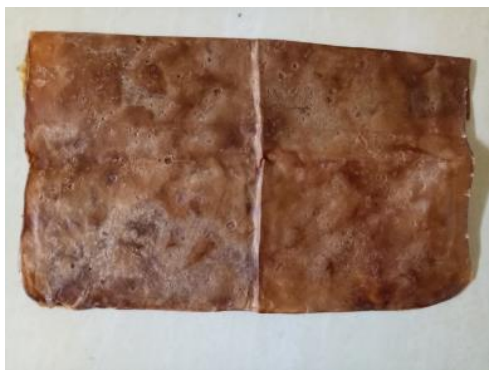

Gambar 6. Selulosa mikrobial dari batang pisang

\section{Sintesis Metil Selulosa}

Sintesis metil selulosa merupakan tahap lanjutan dari selulosa mikrobial yang disintesis dari batang pisang. Beberapa senyawa turunan selulosa diperoleh dengan cara mengganti beberapa gugus hidroksil dalam rantai selulosa dengan bermacammacam gugus organik. Hal ini akan mengubah struktur kristal selulosa dan menjadikannya mudah terdispersi dalam air. Perubahan sifat hidrofilik ada hubungannya dengan derajat substitusi [13].

Selulosa mikrobial direndam dengan $\mathrm{NaOH}$ $50 \%$ selama 24 jam. Perendaman ini merupakan proses swelling yang bertujuan untuk mengaktifkan gugus-gugus - $\mathrm{OH}$ pada molekul selulosa mikrobial dari batang pisang dan sebagai pengembang sehingga memudahkan proses difusi reagen (gugus metil) untuk masuk membentuk ikatan. Kemudian dilakukan proses penyaringan untuk membuang larutan $\mathrm{NaOH}$ sebelum dilakukan proses metilasi. Tahapan metilasi dilakukan dengan menggunakan perbandingan dua pelarut yaitu air dan aseton. Pelarut digunakan sebagai tambahan pada reagen metilasi dikarenakan reagen yang digunakan yaitu metilen klorida yang memiliki titik didih dibawah suhu $50^{\circ} \mathrm{C}$, sehingga akan mudah menguap. Sedangkan reaksi metilasi harus dilakukan pada suhu antara $50-60^{\circ} \mathrm{C}$. Air dan aseton memiliki titik didih di atas suhu $50-60^{\circ} \mathrm{C}$. Ragam pelarut ini juga digunakan sebagai pembanding untuk mendapatkan nilai rasio $\mathrm{OH}$ dan rasio $\mathrm{CH}$.

Konsentrat diambil dan ditambahkan masing-masing pelarut air dan aseton. Reagen metilen klorida ditambahkan tetes demi tetes agar proses metilasi berlangsung sempurna. Reaksi yang terjadi yaitu metilasi dengan penggantian gugus $-\mathrm{H}$ pada $-\mathrm{OH}$ selulosa mikrobial dari batang pisang dengan gugus metil dari metilen klorida. -OH yang dapat termetilasi yaitu pada posisi $\mathrm{C}_{2}, \mathrm{C}_{3}$, dan $\mathrm{C}_{6}$. Substituen dengan berat molekul tinggi lebih memilih gugus hidroksil yang pertama pada atom karbon nomor $6 \quad\left(\mathrm{C}_{6}\right)$ karena keberadaan $\mathrm{C}_{6}$ merupakan karbon terluar sehingga kemungkinan besar gugus $-\mathrm{CH}_{3}$ akan mengganti gugus $-\mathrm{OH}$ pada $\mathrm{C}_{6}$ terlebih dahulu sebelum $\mathrm{C}_{2}$ dan $\mathrm{C}_{3}$. Umumnya, substituen didistribusi bergantung pada ukuran, reaktivitas dan polaritasnya, serta kondisi reaksinya. Selain sebagai pelarut aseton juga memiliki fungsi lain yaitu dapat memudahkan atau memodifikasi pemutusan ikatan hidrogen. Hidrogen mudah lepas dari -OH dan terjadi metilasi $-\mathrm{CH}_{3}$ berikatan dengan $\mathrm{O}$. Selain itu, aseton dapat mengoptimalkan nilai derajat substitusi (DS). Proses metilasi dilakukan refluks selama 6 jam.

Selanjutnya penambahan asam asetat $10 \%$ untuk penetralan. Pencucian dengan air hangat untuk menghilangkan bau asam karena metil selulosa tidak larut pada air panas, tetapi larut pada air dingin jika nilai DS nya optimum. Kemudian disaring dan dikeringkan pada suhu $50^{\circ} \mathrm{C}$ selama 6 jam sehingga diperoleh metil selulosa dari batang pisang berupa serbuk berwarna putih yang dapat dilihat pada Gambar 7.

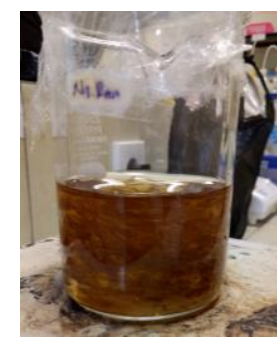

(a)

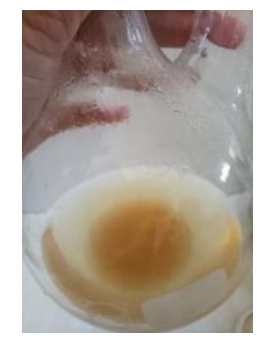

(b)

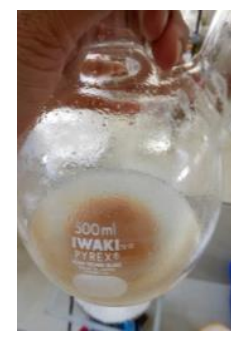

(c)
Gambar 7. (a) Hasil swelling, (b) hasil refluks metil selulosa dengan perlakuan air, (c) hasil refluks metil selulosa dengan perlakuan aseton. 


\section{Karakterisasi Selulosa Mikrobial dan Metil Selulosa dengan FTIR}

Selulosa mikrobial dan metil selulosa dikarakterisasi menggunakan FTIR untuk mengetahui gugus fungsi yang terdapat di dalamnya. Adapun hasil FTIR dari selulosa mikrobial dan metil selulosa dilihat pada Gambar 8 dan Gambar 9. Hasil analisis gugus fungsi menggunakan FTIR dilakukan dengan menginterpretasikan puncak-puncak serapan dari spektrum inframerah. Selain itu, bisa membuktikan keberadaan metil selulosa.

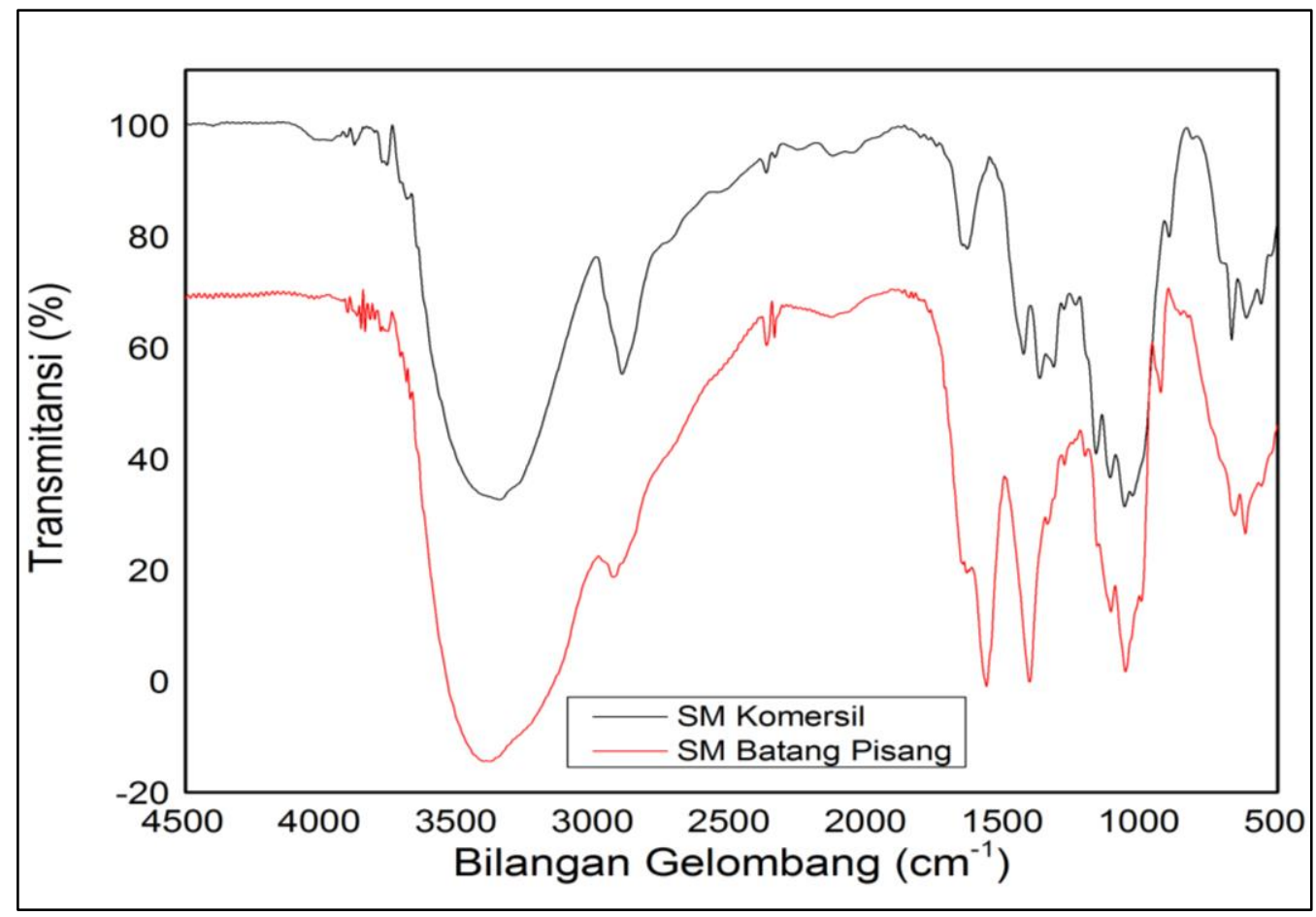

Gambar 8. Hasil FTIR selulosa mikrobial (SM).

Berdasarkan pada Gambar 8 terlihat bahwa hasil spektrum IR selulosa mikrobial terdapat puncak pada panjang gelombang $1568,12 \mathrm{~cm}^{-1}$ yang menunjukkan keberadaan gugus $\mathrm{C}=\mathrm{C}$ pada cincin aromatik lignin. Hemiselulosa terlihat pada puncak dengan panjang gelombang $1408,04 \mathrm{~cm}^{-1}$. Kedua gugus tersebut memperlihatkan keberadaan lignin dan hemiselulosa. Selain itu, selulosa mikrobial dapat dianalisa berdasarkan serapan gugus - $\mathrm{OH}$ streching yang muncul pada daerah serapan $3600 \mathrm{~cm}^{-1}-3300 \mathrm{~cm}^{-1}$. Spektrum selulosa mikrobial batang pisang mucul gugus $-\mathrm{OH}$ streching pada panjang gelombang $3388,93 \mathrm{~cm}^{-1}$. Kemudian memiliki gugus $-\mathrm{CH}$ streching yang muncul pada panjang gelombang sekitar 2931,80 $\mathrm{cm}^{-1}$. Terlihat gugus fungsi $\mathrm{C}-\mathrm{O}$ glikosida (bending) pada panjang gelombang sekitar 927,76 $\mathrm{cm}^{-1}$ dan puncak serapan $\mathrm{C}-\mathrm{O}$ bending diwakili oleh spektrum dengan puncak serapan pada bilangan gelombang $1111,00 \mathrm{~cm}^{-1}$. Gugus fungsi $\mathrm{OH},-\mathrm{CH}$ dan $\mathrm{C}-\mathrm{O}$ glikosidik merupakan gugus utama selulosa dilihat pada Tabel 1 [14].
Tabel 1. Hasil FTIR selulosa dan metil selulosa

\begin{tabular}{|c|c|c|c|}
\hline \multicolumn{3}{|c|}{ Panjang Gelombang $\left(\mathrm{cm}^{-1}\right)$} & \multirow{3}{*}{ Gugus } \\
\hline \multirow{2}{*}{ Selulosa } & \multicolumn{2}{|c|}{ Metil Selulosa } & \\
\hline & MS-aseton & MS-air & \\
\hline 3388,93 & 3446,79 & 3429,43 & $\mathrm{OH}$ regangan \\
\hline 2931,80 & 2900,94 & 2918,30 & $\begin{array}{l}\mathrm{CH} \text { regangan dari } \\
\mathrm{CH}_{2} \text { dan } \mathrm{CH}_{3}\end{array}$ \\
\hline 1639,49 & 1641,42 & 1637,56 & $\begin{array}{l}\text { Regangan } \\
\text { karbonil dengan } \\
\text { cincin aromatik }\end{array}$ \\
\hline 1568,12 & & & $\begin{array}{l}\mathrm{C}=\mathrm{C} \text { regangan } \\
\text { dari cincin } \\
\text { aromatik (lignin) }\end{array}$ \\
\hline 1340,52 & 1377,17 & 1377,12 & C-H deformasi \\
\hline 1280,73 & 1274,96 & 1230,58 & $\mathrm{C}-\mathrm{O}$ regangan \\
\hline 1111,00 & 1159,21 & 1157,28 & $\begin{array}{l}\mathrm{C}-\mathrm{O}-\mathrm{C} \\
\text { antisimetris }\end{array}$ \\
\hline 1056,99 & 1062,78 & 1066,64 & $\begin{array}{l}\mathrm{C}-\mathrm{O} \text { regangan } \\
\text { simetris dari } \\
\text { alkohol primer }\end{array}$ \\
\hline 927,76 & 894,97 & 896,90 & $\begin{array}{l}\text { Ikatan } \beta \text { - } \\
\text { glikosidik antar } \\
\text { unit gula }\end{array}$ \\
\hline
\end{tabular}

Pada Gambar 9 dapat diketahui bahwa hasil spektrum IR metil selulosa memiliki perbedaan yang signifikan jika dibandingkan dengan hasil spektrum IR pada selulosa mikrobial. 


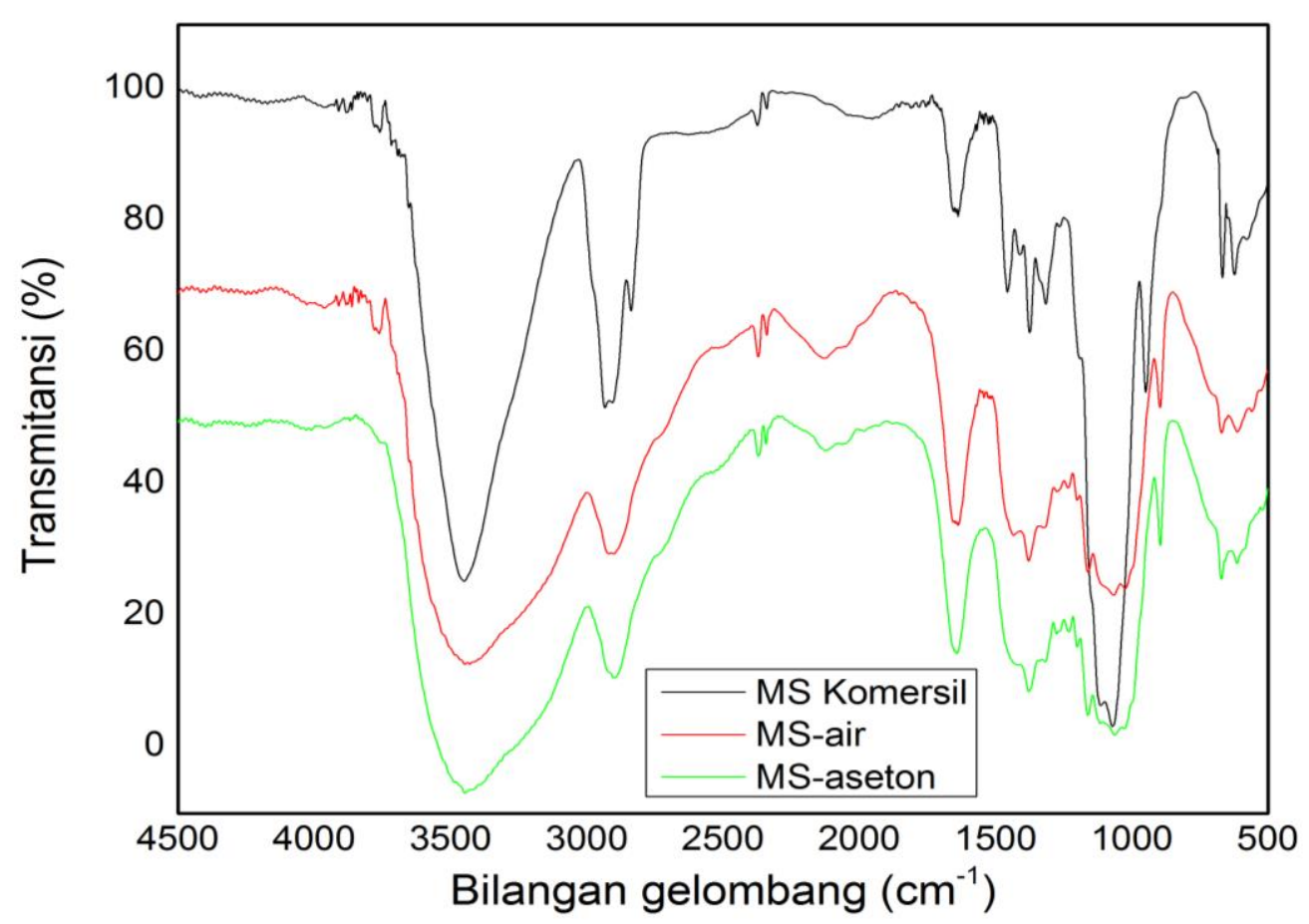

Gambar 9. Hasil FTIR metil selulosa

Pada hasil FTIR metil selulosa tidak ditemukan keberadaan gugus $\mathrm{C}=\mathrm{C}$ pada cincin aromatik lignin sementara dalam selulosa masih terdapat lignin. Kemudian perbedaan yang utama yaitu semakin tajamnya puncak pada daerah serapan gugus $-\mathrm{CH}$ yang menunjukkan berhasilnya proses metilasi. Pada MS-air dan MS-aseton terdapat puncak pada panjang gelombang 2918,30 $\mathrm{cm}^{-1}$ dan 2900,94 $\mathrm{cm}^{-1}$ yang menunjukkan keberadaan gugus $-\mathrm{CH}$. Pada spektrum IR metil selulosa terdapat gugus fungsi $-\mathrm{CH}$ yang terlihat signifikan sedangkan pada spektrum IR selulosa mikrobial tidak terlihat puncak yang tajam. Hal ini membuktikan bahwa selulosa mikrobial sudah termetilasi membentuk metil selulosa.

Dilihat dari perhitungan rasio $\mathrm{O}-\mathrm{H}$ dan rasio $\mathrm{C}-\mathrm{H}$, metil selulosa dengan menggunakan pelarut aseton cenderung lebih efektif dibandingkan dengan metil selulosa yang menggunakan pelarut air. Rasio O-H metil selulosa air $(0,542)$ lebih rendah daripada metil selulosa aseton $(0,547)$, dan dari rasio C-H metil slulosa air $(0,287)$ lebih rendah daripada metil selulosa aseton $(0,304)$.

\section{Uji Sifat Fisika dan Kimia Metil Selulosa}

Metil selulosa dilakukan pengujian warna, titik leleh dan kelarutan. Dilihat secara kasat mata metil selulosa hasil sintesis dari batang pisang berupa serbuk berwarna putih kecoklatan. Terdapatnya warna coklat dimungkinkan pencucian yang kurang bersih sehingga ada pengotor atau sisa-sisa lignin yang menempel.
Pengujian titik leleh dilakukan dengan digantungnya pipa kapiler berisi metil selulosa diatas permukaan air panas. Titik leleh metil selulosa tidak dapat diukur sampai suhu $230^{\circ} \mathrm{C}$. Dimungkinkan metil selulosa yang terbentuk masih mengandung selulosa atau hanya sedikit gugus fungsi $-\mathrm{OH}$ yang termetilasi sehingga masih memiliki sifat seperti selulosa karena titik leleh selulosa adalah $290^{\circ} \mathrm{C}$ [15].

Beberapa senyawa turunan selulosa diperoleh dengan mengganti beberapa gugus hidroksil dalam rantai selulosa dengan bermacammacam gugus organik. Tujuannya yaitu mengubah struktur kristal selulosa dan menjadikannya mudah terdispersi dalam air yaitu metil selulosa. Perubahan sifat hidrofilik ada hubungannya dengan derajat substitusi.

Pengujian kelarutan dilakukan pada 3 media pelarut yaitu air dingin $5^{\circ} \mathrm{C}, \mathrm{NaOH} 4 \%$ dan asam asetat glasial. Fungsi pengujian kelarutan ini untuk mengetahui nilai DS metil selulosa. Hasil uji kelarutan metil selulosa tidak larut pada asam asetat glasial, tidak larut pada air dingin dan tidak larut pada $\mathrm{NaOH} \mathrm{4 \%}$. Hal ini sesuai dengan rentang nilai DS bahwa DS MS-aseton dan DS MS-air tidak berada pada rentang DS tersebut, sehingga tidak larut pada ketiga media pelarut tersebut.

Salah satu fungsi dari metil selulosa yaitu sebagai zat aditif makanan yang merupakan pengemulsi. Dalam konteks aditif makanan, pengemulsi adalah bahan tambahan pangan untuk membantu terbentuknya campuran yang homogen dari dua atau lebih fasa yang tidak tercampur 
seperti minyak dan air. Pengemulsi makanan memiliki nilai DS 1,3-2,6. Berdasarkan hal tersebut metil selulosa yang diperoleh belum bisa diaplikasikan sebagai pengemulsi makanan karena memiliki nilai DS yang rendah. Hal yang menyebabkan nilai DS metil selulosa rendah yaitu sedikitnya gugus - $\mathrm{OH}$ yang termetilasi.

\section{SIMPULAN}

Dari hasil penelitian ini dapat ditarik kesimpulan bahwa selulosa mikrobial berhasil disintesis dengan munculnya pita puncak serapan $\mathrm{OH}$ (regangan), - $\mathrm{CH}$ (regangan), dan $\mathrm{C}-\mathrm{O}-\mathrm{C}$ glikosidik pada masing-masing yang menunjukkan bilangan gelombang $3388,93 \mathrm{~cm}^{-1}, 2931,80 \mathrm{~cm}^{-1}$, dan $927,76 \mathrm{~cm}^{-1}$. Berdasarkan data FTIR, metil selulosa dengan perlakuan air dan aseton berhasil disintesis dengan munculnya puncak serapan masing-masing pada -OH (regangan) $3429,43 \mathrm{~cm}^{-1}$ dan $3446,79 \mathrm{~cm}^{-1}$, $-\mathrm{CH}$ (regangan) $2918,30 \mathrm{~cm}^{-1}$ dan $2900,94 \mathrm{~cm}^{-1}$, C-O glikosida $896,90 \mathrm{~cm}^{-1}$ dan $894,97 \mathrm{~cm}^{-1}$. Rasio O-H metil selulosa dengan perlakuan air $(0,542)$ lebih rendah daripada metil selulosa dengan perlakuan aseton $(0,547)$ dan dari rasio $\mathrm{C}-\mathrm{H}$ metil selulosa dengan perlakuan air $(0,287)$ lebih rendah daripada metil selulosa dengan perlakuan aseton $(0,304)$, hal ini menunjukkan metil selulosa dengan perlakuan aseton lebih efektif daripada metil selulosa dengan perlakuan air.

\section{REFERENSI}

[1] S. Atun, R. Arianingrum, S. Handayani, Rudyansah, and M. Garson "Identifikasi dan Uji Aktivasi Antioksidan Senyawa Kimia dari Ekstrak Metanol Kulit Buah Pisang (Musa paradisiaca L.)", Indonesian Journal of Chemistry, vol. 7, no. 1, pp. 83-87, 2007.

[2] H. Rahman, Pembuatan Pulp dari Batang Pisang Uter (Musa paradisiaca Linn. var uter) Pascapanen dengan Proses Soda, Skripsi, Fakultas Kehutanan, Yogyakarta: Universitas Gadjah Mada, 2006.

[3] Prihandana, Bioetanol Ubi Kayu Bahan Bakar Masa Depan, Jakarta: Agromedia, 2007.

[4] Syafrudin, Pengaruh Konsentrasi Larutan dan Waktu Pemasakan Terhadap Rendemen dan Sifat Fisis Pulp Batang Pisang Kepok (Musa spp) Pascapanen, Skripsi, Fakultas kehutanan, Yogyakarta: Universitas Gadjah mada, 2004.
[5] J.K. Jackson, K. Letchford, B.Z. Wasserman, L. Ye, W.Y. Hamad, and H.M. Burt, "The Use of Nanocrystalline Cellulose for The Binding and Controlled Release of Drugs", International Journal of Nanomedicine, vol. 6, pp. $321-330,2011$.

[6] A.S. Yandri, Zat Aditif, Makalah Seminar Kimia Expo X, Lampung: Jurusan Kimia FMIPA Universitas Lampung, 2006.

[7] L. Rahmidar, I. Nurilah, and T. Sudiarti. "Karakterisasi Metil Selulosa Yang Disintesis Dari Kulit Jagung (Zea Mays)", PENDIPA Journal of Science Education, vol. 2, no. 1, pp. 117-122, 2018.

[8] Z. Cheng, R. Yang, and X. Liu. "Production of bacterial cellulose by Acetobacter xylinum through utilizing acetic acid hydrolysate of bagasse as low-cost carbon source", Bioresources, vol. 12, no. 1, pp. 1190-1200, 2017.

[9] L. Luo, H. Meng, and J.D. Gu. "Microbial extracellular enzymes in biogeochemical cycling of ecosystems", Journal of Environmental Management, vol. 197, pp. 539-549, 2017.

[10] J. Ye, S. Zheng, Z. Zhang, F. Yang, K. Me, Y. Feng, J. Zheng, D. Mao, X. Yang et al., "Bacterial cellulose production by Acetobacter xylinum ATCC 23767 using tobacco waste extract as culture medium", Bioresource Technology vol. 274, pp. 518524, 2019.

[11] T. Wustenberg, Cellulose and Cellulose Derivatives in Food Industry, Germany: Markono Print Media, 2015.

[12]C. Silva, G.T.d.M. Silva, T.d.S. and Costa, V.M.T. "Chromophores inspired by the colors of fruit, flowers and wine", Pure and Applied Chemistry, vol. 92, no. 2, pp. 255-263, 2020.

[13]Fengel dan Wegeneer, Kayu: Kimia, Ultrasruktur, Reaksi-reaksi. Terjemahan oleh Sastrohamidjojo, H, Yogyakarta: Gajah Mada University Press, 1995.

[14]M.E. Fuller, C. Andaya, and K. McClay. "Evaluation of ATR-FTIR for analysis of bacterial cellulose impurities", Journal of Microbiological Methods vol. 144, pp. 145151, 2018.

[15]L. Rahmidar, S. Wahidiniawati, and T. Sudiarti, "Pembuatan dan karakterisasi metil selulosa dari bonggol dan kulit nanas (Ananas comosus)", Alotrop, vol 2, no. 1, pp. 88-96, 2018. 